\title{
Purification and characterization of an amyloglucosidase from an ericoid mycorrhizal fungus (Leohumicola incrustata)
}

\author{
O. R. Adeoyo ${ }^{1,2}$, B. I. Pletschke ${ }^{1}$ and J. F. Dames ${ }^{1 *}$
}

\begin{abstract}
This study aimed to purify and characterize amyloglucosidase (AMG) from Leohumicola incrustata. AMG was purified to homogeneity from cell-free culture filtrate of an ERM fungus grown in a modified Melin-Norkrans liquid medium. The molecular mass of the AMG was estimated to be 101 kDa by combining the results of Sephadex G-100 gel filtration, sodium dodecyl sulphate-polyacrylamide gel electrophoresis, and zymography. The $K_{m}$ and $k_{\text {cat }}$ values were $0.38 \mathrm{mg} \mathrm{mL}^{-1}$ and $70 \mathrm{~s}^{-1}$, respectively, using soluble starch as a substrate. The enzyme was stable at $45^{\circ} \mathrm{C}(\mathrm{pH} 5.0)$, retaining over $65 \%$ activity after a pre-incubation period of $24 \mathrm{~h}$. The metal inhibition profile of the AMG showed that $\mathrm{Mn}^{2+}$ and $\mathrm{Ca}^{2+}$ enhanced activity, while it was stable to metals ions, except a few $\left(\mathrm{Al}^{3+}, \mathrm{Co}^{2+}, \mathrm{Hg}^{2+}\right.$ and $\left.\mathrm{Cd}^{2+}\right)$ that were inhibitory at a concentration higher than $5 \mathrm{mM}$. Thin layer chromatography revealed that only glucose was produced as the product of starch hydrolysis. The amylase from L. incrustata is a glucoamylase with promising characteristics such as temperature stability over an extended period, high substrate affinity and stability to a range of chemicals. Also, this study reports for the first time the possibility of using some culturable ERM fungi to produce enzymes for the bio-economy.
\end{abstract}

Keywords: Amyloglucosidase, Chromatography, Ericoid mycorrhiza, Starch, Zymography

\section{Introduction}

Leohumocola incrustata is a genus of mycorrhizas commonly found within the roots of ericaceous plants. Ericaceous plants belong to a family of plants that can alter their physiological or morphological characteristics in nutrient deficient ecosystems. The survival of ericaceous plants in nutrient-deficient soils depends strongly on the symbiotic association that exists between them and mycorrhizal fungi, where nutrients are made available from soil organic matter through the assistance of hydrolytic enzymes. Ericoid mycorrhizal (ERM) fungi have been found to produce hydrolytic enzymes (Cairney and Burke 1994, 1998) which include the production of amyloglucosidase. Other reports have also indicated that the enzymatic degradation of organic polymers in the soil and the

\footnotetext{
*Correspondence: J.Dames@ru.ac.za

1 Department of Biochemistry and Microbiology, Rhodes University,

P.O. Box 94, Grahamstown 6140, South Africa

Full list of author information is available at the end of the article
}

transfer of some of the resulting products to the root is a significant benefit to the growth and development of ericaceous plants (Smith and Read 2008). A new area of biotechnological research now focuses on the production and characterization of enzymes from various sources with unique properties (Karim et al. 2017). Some of the desired characteristics of industrial enzymes include thermostability, specificity and $\mathrm{pH}$ stability. The application of amylases has increased over the years in areas such as juice processing, processing of starch, resizing of textiles, paper sizing, detergent additives, malting barley and bakery industries (Singh et al. 2016; Rana et al. 2017; Raveendran et al. 2018).

Alpha-amylase and glucoamylase are the two major classes of amylases, mostly identified among microorganisms (John 2017). Alpha-amylases are exo-acting enzymes that randomly cleave the 1,4- $\alpha$-D-glucosidic linkages between adjacent glucose units in the linear amylose chain. Amyloglucosidase (AMG, glucoamylase, EC 3.2.1.3) is an enzyme that is capable of hydrolyzing 
the $\alpha-1,4$ glycosidic bonds from the non-reducing ends of starch to produce glucose. It is also an exo-acting enzyme that catalyzes the production of $\beta$-D-glucose from the non-reducing ends of substrates that include starch, and maltooligosaccharides by consecutively hydrolyzing $\alpha-1,4$ and $\alpha-1,6$ linkages (Sauer et al. 2000; Riaz et al. 2012; John 2017; Raveendran et al. 2018).

Starch is one of the most abundantly distributed polysaccharides produced by plants. It is made up of two molecular weight polymers, amylose and amylopectin. Amylose is a linear chain of glucose residues linked by $\alpha-1,4$ bonds while amylopectin is a branched polymer with $\alpha$-1,4-linked and $\alpha$-1,6-linked glucose residues. AMG serves as a raw material for fermentation in the production of ethanol, glucose syrups, and in some cases can be used to improve barley mash for beer production (Aiyer 2005; Zambare 2010). Consequently, AMG can be considered as an economically significant enzyme because of its effectiveness in hydrolyzing starch and some oligosaccharides into $\beta$-D-glucose. Glucoamylase has been reported in Rhizopus oryzae (Morita and Fujio, 2000), Aspergillus awamori (Negi and Banerjee 2009), Aspergillus niger (Slivinski et al. 2011), as well as in two ectomycorrhizal fungi, Tricholoma matsutake and Lyophyllum shimeji (Hur et al. 2001; Kusuda et al. 2004). Kusuda et al. 2004 characterized an extracellular glucoamylase from $L$. shimeji, stating that the enzyme was most active at around $40{ }^{\circ} \mathrm{C}$. More recently, this enzyme has been reported to be produced from some microorganisms, viz, Aspergillus flavus (Karim et al. 2017) and Tetracladium sp. (Carrasco et al. 2017). In this study, an amyloglucosidase from $L$. incrustata was purified and characterized.

\section{Materials and methods}

\section{Culture}

An ericoid mycorrhizal fungus, L. incrustata (Isolate code ChemRU330/Genbank accession no: MF374380/ South African National Collection of Fungi accession no: PPRI 17268), was obtained from the Mycorrhizal Research Laboratory, Rhodes University, Department of Biochemistry and Microbiology, Rhodes University, Grahamstown, South Africa. The isolate was maintained on potato dextrose agar (PDA). Incubation was performed at $28{ }^{\circ} \mathrm{C}$ for 21 days. The mycelia were kept on PDA, stored at $4{ }^{\circ} \mathrm{C}$ and regularly subcultured throughout the study period.

\section{Production of amylase}

Soluble Starch (1\% w/v, Merck, Cas \# 9005-84-9) was added to a $1000 \mathrm{~mL}^{-1}$ Erlenmeyer flask in an modified Melin-Norkrans (MMN) broth with the composition: $\left(\mathrm{g} \mathrm{L}^{-1}\right)$ : glucose 1.0; yeast extract 3.0; malt extract
1.0; $\left(\mathrm{NH}_{4}\right)_{2} \mathrm{HPO}_{4} \quad 0.25 ; \quad \mathrm{KH}_{2} \mathrm{PO}_{4} \quad 0.50 ; \quad \mathrm{MgSO}_{4} \cdot 7 \mathrm{H}_{2} \mathrm{O}$ 0.15; $\mathrm{CaCl}_{2}$ 0.05; $\mathrm{NaCl}$ 0.025; thiamine- $\mathrm{HCl} 100 \mu \mathrm{g} \mathrm{L}{ }^{-1}$, $\mathrm{ZnSO}_{4} \cdot 7 \mathrm{H}_{2} \mathrm{O} 0.003$, and $1.2 \mathrm{~mL}$ of $\mathrm{FeCl}_{3}(1 \% \mathrm{w} / \mathrm{v})$. Production medium was thoroughly mixed, and a $250 \mathrm{~mL}$ was placed in a $500 \mathrm{~mL}$ shake flask. The medium was sterilized at $121{ }^{\circ} \mathrm{C}$ for 15 min and was inoculated with five discs of $5 \mathrm{~mm}$ mycelial plugs of the fungus. The uninoculated medium was used as a control. Growth was allowed to proceed at $28{ }^{\circ} \mathrm{C}$ in the dark for 3 weeks on a rotary incubator shaker at $150 \mathrm{rpm}$. After 42 days of growth, the cultures were homogenised using IKA's ULTRA-TURRAX homogeniser (20,000 rpm), and centrifugation was performed at $10,000 \times g$ for $15 \mathrm{~min}$ to obtain crude enzyme filtrates (supernatant) using a Beckman Coulter Avanti-J high-speed centrifuge.

\section{Assay for amylase}

A dinitrosalicylic acid (DNS) assay (Miller 1959) was conducted by adding $1 \%(\mathrm{w} / \mathrm{v})$ soluble starch to a volume of $10 \mathrm{~mL}$ sodium acetate buffer (pH 5.0) in a Schott bottle and boiled for $30 \mathrm{~s}$. A volume of $100 \mu \mathrm{L}$ of crude enzyme and uninoculated control was added to $300 \mu \mathrm{L}$ of the soluble starch-containing medium in triplicate, while the blank contained $400 \mu \mathrm{L}$ buffer. All samples were incubated at $37^{\circ} \mathrm{C}$ for $1 \mathrm{~h}$, followed by centrifugation at $6000 \times g$ for $2 \mathrm{~min}$. A $300 \mu \mathrm{L}$ aliquot of DNS was added to $150 \mu \mathrm{L}$ of each supernatant sample. This was followed by boiling on a heating block at $100{ }^{\circ} \mathrm{C}$ for 5 min after which it was cooled on ice for $5 \mathrm{~min}$. A volume of $250 \mu \mathrm{L}$ of each sample was placed into each well of a 96-well plate and read with the aid of a spectrophotometer (BioTek's Synergy Mx) at a wavelength of $540 \mathrm{~nm}$. The supernatant was taken to determine the reducing sugar using DNS assay with glucose as a standard.

\section{Protein analysis}

Protein content was determined with Bradford reagent assay kit using bovine serum albumin as standard (Bradford 1976).

\section{Ammonium sulphate precipitation}

A $120 \mathrm{~mL}$ volume of the crude enzyme was brought to $80 \%$ saturation with solid ammonium sulphate according to the method of Kusuda et al. (2004). The mixture was left overnight at $4{ }^{\circ} \mathrm{C}$ on a magnetic stirrer. The pellet obtained from the centrifuged mixture was re-dissolved in $20 \mathrm{mM}$ sodium acetate buffer ( $\mathrm{pH} 5.0)$ to make up a volume of $10 \mathrm{~mL}$.

\section{Dialysis of the partially purified enzyme}

A pre-treated dialysis bag was used for the dialysis (10 kDa cut-off) of the enzyme collected after ammonium sulphate precipitation. The partially purified 
enzyme $(10 \mathrm{~mL})$ was dialyzed against $20 \mathrm{mM}$ sodium acetate buffer $(\mathrm{pH} 5.0)$ at $4{ }^{\circ} \mathrm{C}$ with three changes of a buffer according to the method described by Kusuda et al. (2004).

\section{Gel filtration}

A vertical glass chromatographic column $(1.5 \times 50 \mathrm{~cm})$ was packed using Sephadex G-100. The dialyzed enzyme solution $(1.5 \mathrm{~mL})$ was used after it was concentrated by ultrafiltration (Amicon Ultra-100 centrifugal filter device; cut-off $10 \mathrm{kDa}$ ). Gel filtration chromatography was carried out using sodium acetate buffer (20 mM, pH 5.0), at a flow rate of $1.2 \mathrm{~mL} \mathrm{~min}^{-1}$. All fractions collected were subjected to analysis by measuring the absorbance at $280 \mathrm{~nm}$, followed by the activity assay, the active fractions (fractions no. 36-40; $5 \mathrm{~mL}$ ) were pooled together afterwards.

\section{Identification of hydrolytic products using thin layer chromatography (TLC)}

Soluble starch was used as the substrate. The mixture was incubated in a dry heating block at $45{ }^{\circ} \mathrm{C}$ for 1 min up to $24 \mathrm{~h}$ and samples were removed at various time intervals for analysis. Samples were then boiled for $5 \mathrm{~min}$ at $100{ }^{\circ} \mathrm{C}$ to denature the proteins and then centrifuged at $6000 \times g$ for $5 \mathrm{~min}$. The supernatant $(80 \mu \mathrm{L})$ was used for TLC analysis. Identical volumes $(5 \mu \mathrm{L})$ of the supernatant were applied to Silica Gel 60G F254 HPTLC plates (Merck, Darmstadt, Germany). Plates were developed twice with n-butanol: acetic acid: water $(2: 1: 1, \mathrm{v} / \mathrm{v} / \mathrm{v})$. Then, to detect carbohydrates, plates were briefly submerged in methanol containing $5 \%(\mathrm{v} / \mathrm{v})$ sulfuric acid and $0.3 \% \alpha$-naphthol. Plates were then air dried, heated at $120{ }^{\circ} \mathrm{C}$ for $10 \mathrm{~min}$ and observed for the bands formed by various hydrolytic products.

\section{AMG activity staining (zymography)}

The enzyme from crude extract was analyzed by its native protein pattern using the copolymerization method of Martinez et al. (2000). Sample was diluted in $1: 1$ in sample buffer $(0.125 \mathrm{M}$ Tris; $20 \% \mathrm{v} / \mathrm{v}$ glycerol; $0.04 \% \mathrm{v} / \mathrm{v}$ bromophenol blue) and boiled at $95{ }^{\circ} \mathrm{C}$ for $5 \mathrm{~min}$. The resolving gel (12\%) consisted of:- polyacrylamide $4.0 \mathrm{~mL}, 1.5 \mathrm{M}$ Tris- $\mathrm{HCl}$ buffer $(\mathrm{pH} 8.8)$ $2.5 \mathrm{~mL}$, distilled water $2.25 \mathrm{~mL}, 2 \% \mathrm{w} / \mathrm{v}$ soluble starch $1.25 \mathrm{~mL}, 10 \% \mathrm{w} / \mathrm{v}$ sodium dodecyl sulfate (SDS) $100 \mu \mathrm{L}$, $10 \% \mathrm{w} / \mathrm{v}$ ammonium persulfate $50 \mu \mathrm{L}$, and $N, \mathrm{~N}, N^{\prime}, N^{\prime}$ tetramethylethylenediamine (TEMED) $5 \mu \mathrm{L}$. The stacking gel (4\%) consisted of: polyacrylamide $0.65 \mathrm{~mL}$, $0.5 \mathrm{M}$ Tris- $\mathrm{HCl}$ buffer ( $\mathrm{pH}$ 6.8) $1.25 \mathrm{~mL}$, distilled water $3.05 \mathrm{~mL}, 10 \% \mathrm{w} / \mathrm{v}$ SDS $50 \mu \mathrm{L}, 10 \% \mathrm{w} / \mathrm{v}$ ammonium persulfate $25 \mu \mathrm{L}$, and TEMED $5 \mu \mathrm{L}$. Starch-SDSPAGE (PAGE-polyacrylamide gel electrophoresis) was carried out in two phases viz. gels were first subjected to a constant voltage of $30 \mathrm{~V}$ for $30 \mathrm{~min}$ to ensure the tracking dye (bromophenol blue) enters the separating gel. After this, gels were finally subjected to a constant voltage of $100 \mathrm{~V}$ for $75 \mathrm{~min}$. Electrophoresis was carried at a temperature of $0-2{ }^{\circ} \mathrm{C}$ to allow the enzyme to migrate inactively without hydrolyzing the starch. After electrophoresis, the gel was washed in distilled water and then incubated in $0.1 \mathrm{M}$ phosphate-citrate and $0.05 \mathrm{M} \mathrm{NaCl}$ buffer ( $\mathrm{pH}$ 6.0) for $3 \mathrm{~h}$ at $39{ }^{\circ} \mathrm{C}$. Again, gels were washed and fixed in $12 \%$ trichloroacetic acid (TCA) for $10 \mathrm{~min}$, followed by another washing and gently shaking $(50 \mathrm{rpm})$ in $2.5 \% \mathrm{w} / \mathrm{v}$ Triton $\mathrm{X}-100$ for $1 \mathrm{~h}$ at $4{ }^{\circ} \mathrm{C}$ to remove SDS and restore activity. Finally, the gels were stained with Lugol solution $\left(6.7 \mathrm{mg} \mathrm{mL}^{-1}\right.$ $\mathrm{KI}$ and $3.3 \mathrm{mg} \mathrm{mL}^{-1} \mathrm{I}_{2}$ ), and photographs were taken.

\section{Molecular weight determination by SDS-PAGE electrophoresis}

SDS-PAGE was performed using $8 \times 10 \times 0.75 \mathrm{~cm}$ gels in a Mini-Protean II (Bio-Rad) gel apparatus. Samples were treated with reducing (containing 2-mercaptoethanol) sample buffer and boiled for 5 min before loading the gel. After electrophoresis, proteins in the gel were visualized by staining with Coomassie Blue R-250 (Laemmli 1970).

\section{Effect of pH on activity and stability of the AMG}

The optimum $\mathrm{pH}$ for the enzyme was determined by incubating enzyme with the substrate $(1 \%, \mathrm{w} / \mathrm{v})$ prepared in $0.1 \mathrm{M}$ buffer having $\mathrm{pH}$ values of 1.0, 2.0 (hydrochloric acid-potassium chloride); 3.0 (citrate); 4.0, 5.0 (acetate); 6.0, 7.0 (phosphate); 8.0 and 9.0 (Tris- $\mathrm{HCl}$ ) at a temperature of $45^{\circ} \mathrm{C}$ for $1 \mathrm{~h}$, after which the enzyme activity was measured. The $\mathrm{pH}$ stability was determined by preincubating the enzyme in buffers of different $\mathrm{pH}(3.0,4.0$, 5.0, 6.0, 7.0 and 8.0 ) at $37{ }^{\circ} \mathrm{C}$ for $6,12,18,24$ and $30 \mathrm{~h}$ before determining the residual activity by the standard procedure.

\section{Effect of temperature on activity and stability of the AMG}

The optimum $\mathrm{pH}$ for the enzyme was determined by incubating enzyme with the substrate $(1 \% \mathrm{w} / \mathrm{v})$ prepared in 0.1 acetate buffer ( $\mathrm{pH} 5.0)$. The enzyme was incubated at different temperatures of 4, 20, 30, 40, 50, 60, 70 and $80{ }^{\circ} \mathrm{C}$ for $1 \mathrm{~h}$, after which, the enzyme activity was measured. The temperature stability was investigated by preincubating the enzyme at different temperatures (37, $45,50,60$, and $70{ }^{\circ} \mathrm{C}$ ) for $6,12,18,24$ and $30 \mathrm{~min}$ before determination of the residual activity by the standard procedure. 
Effect of metal ions and other additives on the activity of the AMG

Metal ions such as $\mathrm{K}^{+}, \mathrm{Na}^{+}, \mathrm{Ca}^{2+}, \mathrm{Mn}^{2+}, \mathrm{Fe}^{2+}, \mathrm{Mg}^{2+}$, $\mathrm{Al}^{3+}, \mathrm{Hg}^{2+}$, and $\mathrm{Cd}^{2+}$ (all supplied in chloride form) were each applied to determine the effect on the activity of the enzyme. Each metal ion was used at a concentration of 1,5 , and $10 \mathrm{mM}$, while incubation was performed at $45^{\circ} \mathrm{C}$ for $1 \mathrm{~h}$. The following compounds-sodium azide $\left(\mathrm{NaN}_{3}\right)$, dimethyl sulfoxide (DMSO), ethylenediaminetetraacetic acid (EDTA), Tween 20, SDS, and indole-3-acetic acid (IAA) were tested for their inhibitory effect on AMG activity. The purified enzyme was incubated at $45{ }^{\circ} \mathrm{C}$ for $1 \mathrm{~h}$ in $20 \mathrm{mM}$ sodium acetate buffer ( $\mathrm{pH}$ 5.0), containing each inhibitor or denaturing agent at final concentrations of 1,5 , and $10 \mathrm{mM}$, respectively. The relative enzyme activity was determined under standard assay conditions.

\section{Enzyme kinetics}

The Michaelis-Menten substrate saturation curve was used to determine the $K_{m}$ and $V_{\max }$ value of the AMG by measuring the rate of soluble hydrolysis under standard assay conditions. The reaction mixture was $20 \mathrm{mM}$ acetate buffer ( $\mathrm{pH}$ 5.0), with the soluble starch substrate at concentrations ranging from 0.2 to $10 \mathrm{mg} \mathrm{mL}^{-1}$. The values for $K_{m}$ and $V_{\max }$ were then determined using KaleidaGraph.

\section{Statistical analysis}

All experiments were carried out in triplicate. Data were analysed on Microsoft ${ }^{\circledR}$ Excel software, and all values were presented as the standard errors of the means $( \pm$ SEM).

\section{Results}

\section{Purification of enzyme}

The production of AMG from L. incrustata was induced by the addition of soluble starch into a mineral medium at a temperature of $28{ }^{\circ} \mathrm{C}$ for 42 days ( $\mathrm{pH}$ 5.0). Table 1 summarizes the purification steps of the AMG solution prepared from the cell-free culture filtrate $(120 \mathrm{~mL})$. Partial purification of the AMG by ammonium sulphate $\left[\left(\mathrm{NH}_{4}\right)_{2} \mathrm{SO}_{4}\right]$ precipitation was the first step of the purification procedure; the filtrate was precipitated at $80 \%$ saturation. The ammonium sulphate fraction yielded $71 \%$ activity with purification fold of 13.7 and specific activity of $15.8 \mathrm{U} \mathrm{mg}^{-1}$ protein. The dialysis step produced a $54 \%$ activity with purification fold of 18.61 and specific activity of $21.5 \mathrm{U} \mathrm{mg}^{-1}$ protein. The elution profile on Sephadex G-100 showed that peak (b) (Fig. 1) exhibited high AMG activity, while other peaks did not show any noticeable amylase activity. The gel purification step yielded $27 \%$ activity with purification fold of 23.5 and a specific activity of $27.17 \mathrm{U} \mathrm{mg}^{-1}$ protein (Table 1).

\section{Enzyme characterization}

Fractions showing the highest AMG activities (fractions 36-40) were pooled for characterization studies (Fig. 1). Figure 2 shows the pattern of TLC of AMG hydrolysis from $L$. incrustata. The reaction time ranged from 1 to $10 \mathrm{~min}$ (Fig. 2a), $10 \mathrm{~min}$ to $90 \mathrm{~min}$ and $24 \mathrm{~h}$ (Fig. 2b) at $45^{\circ} \mathrm{C}$. A single band of clearance zone was revealed after activity gel analysis, which indicated that the $L$. incrustata released a single isoform of the AMG (Fig. 3). Also, SDS-PAGE was carried out to confirm homogeneity of the enzyme using a 12\% gel. Thus Fig. 3 shows the results of SDS-PAGE and zymography. The molecular weight of the enzyme was estimated to be $101 \mathrm{kDa}$ using a standard curve of $\log (\mathrm{MW})$ versus $\mathrm{R}_{\mathrm{f}}$. Figure 4 shows the result of gel filtration on SDS-PAGE to obtain a single homogeneous protein band (101 kDa).

\section{Effect of $\mathrm{pH}$ on enzyme activity and stability}

Effect of $\mathrm{pH}$ on enzyme activity was tested using reaction mixtures buffered at different $\mathrm{pH}$ values ranging from 1.0 to 9.0, for optimal activity (Fig. 5). The findings showed that the highest activity of the purified enzyme was obtained at $\mathrm{pH} 4.0$, and more than $50 \%$ activity was retained between $\mathrm{pH} 4.0$ to 6.0 . At $\mathrm{pH} 5.0\left(37^{\circ} \mathrm{C}\right)$ over a period of $24 \mathrm{~h}$, the enzyme was $100 \%$ stable (Fig. 6 ). Hence, the enzyme displayed optimal activity under a mildly acidic $\mathrm{pH}$. The AMG activity was also observed to be stable (above $50 \%$ ) up to $6 \mathrm{~h}$ at a $\mathrm{pH}$ of $7.0\left(37^{\circ} \mathrm{C}\right)$ but dropped rapidly after $12 \mathrm{~h}$ (Fig. 6).

Table 1 Purification table of AMG from Leohumicola incrustata

\begin{tabular}{|c|c|c|c|c|c|}
\hline Purification step & Total protein (mg) & Total activity (U) & $\begin{array}{l}\text { Specific activity } \\
\text { (U } \mathrm{g}^{-1} \text { protein) }\end{array}$ & Purification fold & Yield (\%) \\
\hline Cell-free filtrate & 234.709 & 271.080 & 1.155 & 1.000 & 100 \\
\hline$\left(\mathrm{NH}_{4}\right)_{2} \mathrm{SO}_{4}$ & 12.152 & 192.139 & 15.812 & 13.690 & 71 \\
\hline Dialysis & 6.848 & 147.207 & 21.495 & 18.611 & 54 \\
\hline Gel filtration & 2.698 & 73.326 & 27.174 & 23.528 & 27 \\
\hline
\end{tabular}




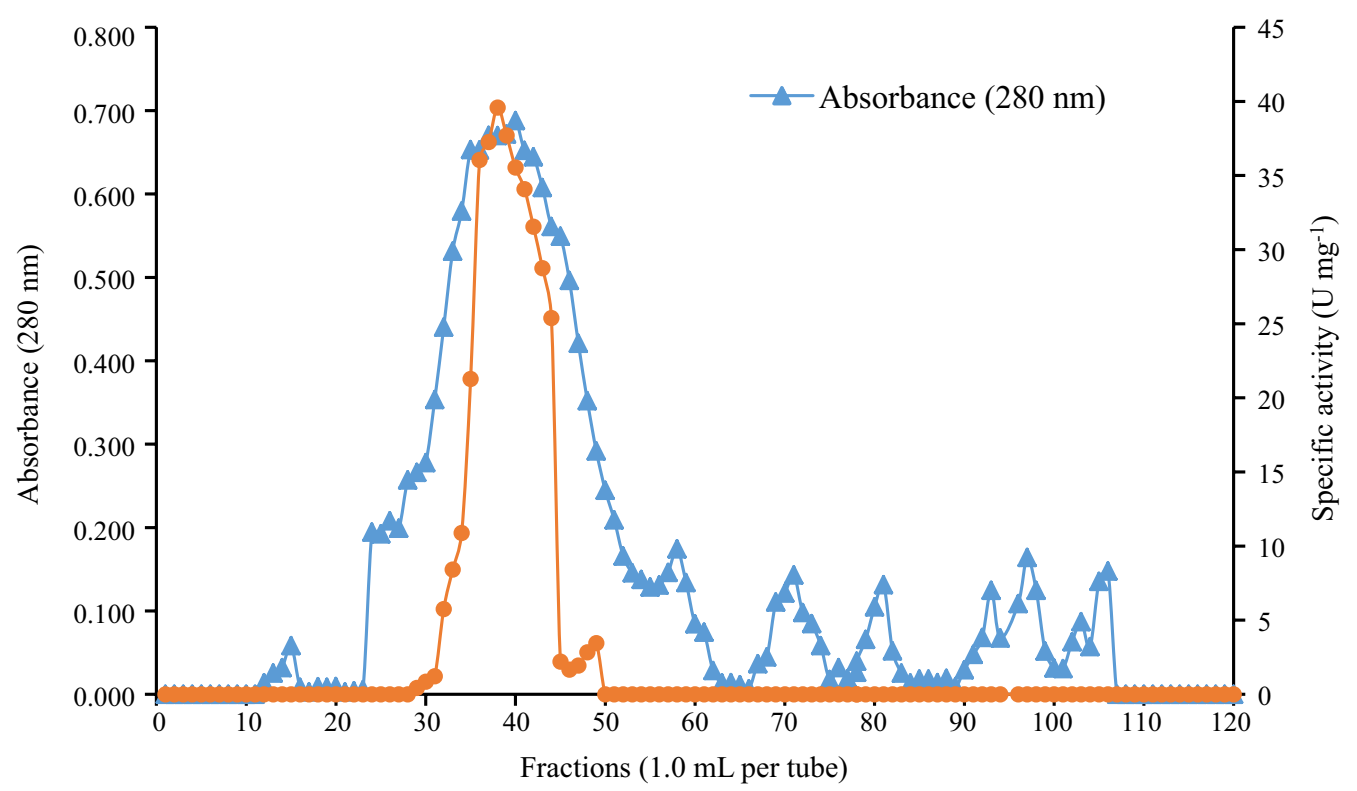

Fig. 1 Chromatogram of the crude enzyme fractions of Leohumicola incrustata on a Sephadex G-100 chromatographic column (flow rate: $1.2 \mathrm{~mL} \mathrm{~min}^{-1}$ )
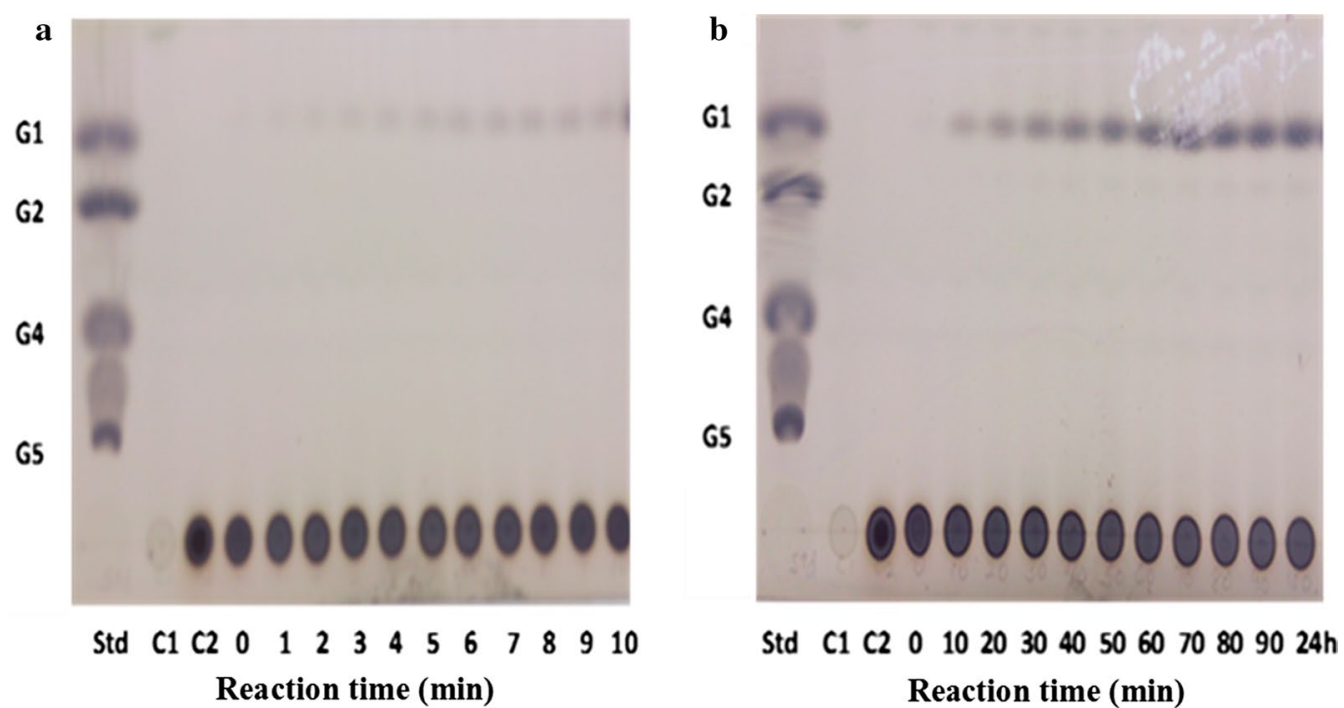

Fig. 2 Thin-layer chromatograms of hydrolyzates. Plates were developed twice with $n$-butanol: acetic acid: water (2:1:1, v/v/v). The plates were briefly submerged in methanol containing $5 \%(\mathrm{v} / \mathrm{v})$ sulfuric acid and $0.3 \%$ a-naphthol. Standard (Std): glucose (G1), maltose (G2), maltotetraose (G4), and maltopentaose (G5), substrate control (C1), enzyme control (C2), reaction time: 0-90 min and $24 \mathrm{~h}$

\section{Effect of temperature on activity and stability of AMG}

The effect of temperature on AMG showed that the enzyme reached its optimum activity at a temperature of $50{ }^{\circ} \mathrm{C}$ (Fig. 7). Lowest activities were observed at $4{ }^{\circ} \mathrm{C}$ and $70{ }^{\circ} \mathrm{C}$, while no apparent activity was recorded at $80{ }^{\circ} \mathrm{C}$ (Fig. 7). The enzyme also displayed its highest stability at $45{ }^{\circ} \mathrm{C}$ and was least stable at $70{ }^{\circ} \mathrm{C}$ (Fig. 8). The enzyme retained at least $65 \%$ of its original activity at a temperature between 37 and $45^{\circ} \mathrm{C}$ up to $30 \mathrm{~h}$, while less than $60 \%$ activity was retained up to $30 \mathrm{~h}$ at a temperature of $50{ }^{\circ} \mathrm{C}$ (Fig. 8). 

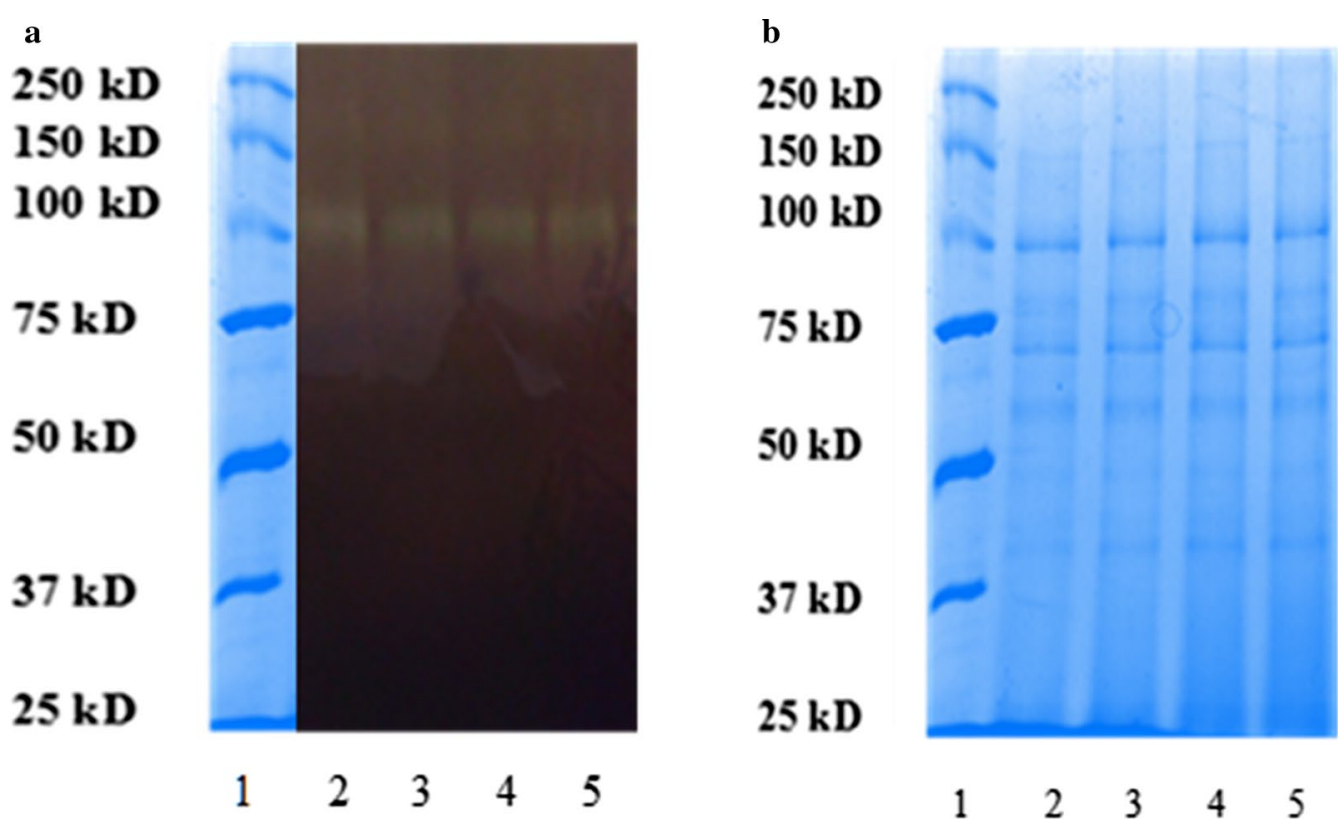

Fig. 3 12\% Zymogram and SDS-PAGE analysis of the AMG prepared according to the method described by Martinez et al. (2000). a Lane 1 is precision plus unstained protein standard (BIO-RAD), lanes 2-5 is a crude enzyme of Leohumicola incrustata (iodine staining); $\mathbf{b}$ lane 1 is precision plus unstained protein standard (BIO-RAD), lanes $2-5$ is SDS-PAGE of crude AMG

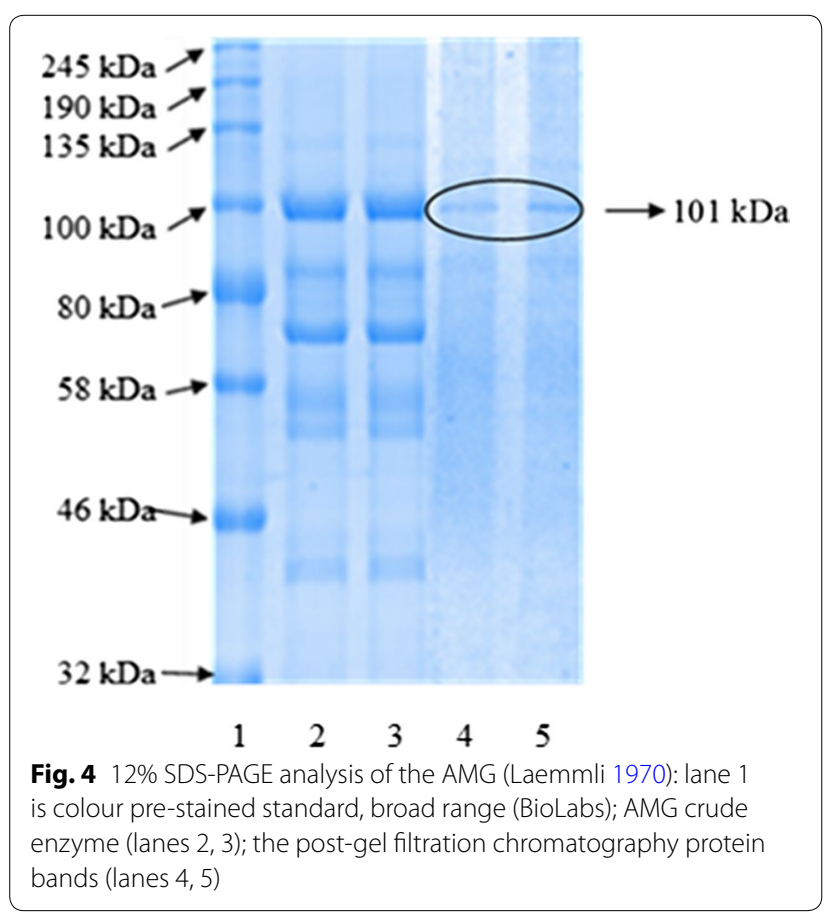

Effect of metal ions and additives on the activity of AMG Table 2 shows the effect of the presence of metal ions on AMG activity measured at $\mathrm{pH} 5.0$ and a temperature of $45{ }^{\circ} \mathrm{C}$. Assays were performed with the addition of each metal ion with the concentration ranging from 1 to $10 \mathrm{mM}$. The chloride salts of these metal ions were used. Manganese $\left(\mathrm{Mn}^{2+}\right)$ and calcium $\left(\mathrm{Ca}^{2+}\right)$ have the highest relative activity values of 112 and $106 \%$ at $10 \mathrm{mM}$ concentration. Cobalt $\left(\mathrm{Co}^{2+}\right)$, mercury $\left(\mathrm{Hg}^{2+}\right)$, cadmium $\left(\mathrm{Cd}^{2+}\right)$ and aluminium $\left(\mathrm{Al}^{3+}\right)$ all inhibited the enzyme, with values of $77,0.45,4$ and $86 \%$, respectively, at the same concentration. Other metal ions tested did not have any significant effect on AMG activity. Table 3, on the other hand, shows the influence of the additives (other chemicals) on AMG activity. SDS had the highest inhibitory effect on the various concentrations used, followed by EDTA at a concentration of $10 \mathrm{mM}$ only, while other tested additives were not inhibitory to the AMG activity.

\section{Enzyme kinetics}

Figure 9 shows the result of a graph after plotting the concentration of starch [S] versus initial velocity $V_{o}$ of AMG enzyme activity. $[\mathrm{S}] / V_{o}$ represents the ratio of starch concentration to the initial velocity of the AMG enzyme activity (Fig. 9). $K_{m}$ represents the Michaelis-Menten constant of the AMG enzyme and $V_{\max }$, the maximum velocity achieved by AMG enzyme-starch reaction. AMG enzyme produced by $L$. incrustata has a $K_{m}$ value of $0.38 \mathrm{mg} \mathrm{mL}^{-1}$ and a $V_{\max }$ value of $22.56 \mathrm{U} \mathrm{mL}^{-1}$. Hence, AMG enzyme produced by $L$. incrustata has a high affinity for starch. The turnover number $\left(k_{\text {cat }}\right)$ and specificity 


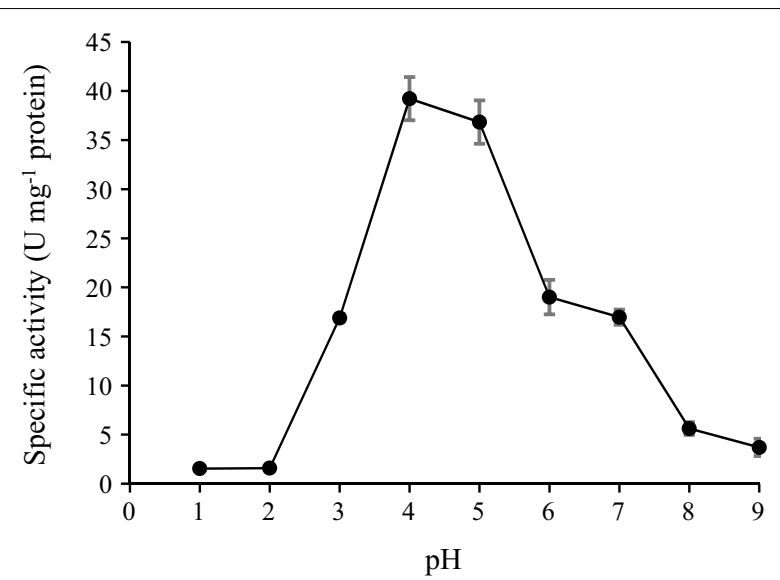

Fig. 5 Effect of pH on Leohumocola incrustata specific activity. The enzyme was incubated at $45^{\circ} \mathrm{C}$ for $1 \mathrm{~h}$. All error bars are represented as the standard errors of the means (SEM)

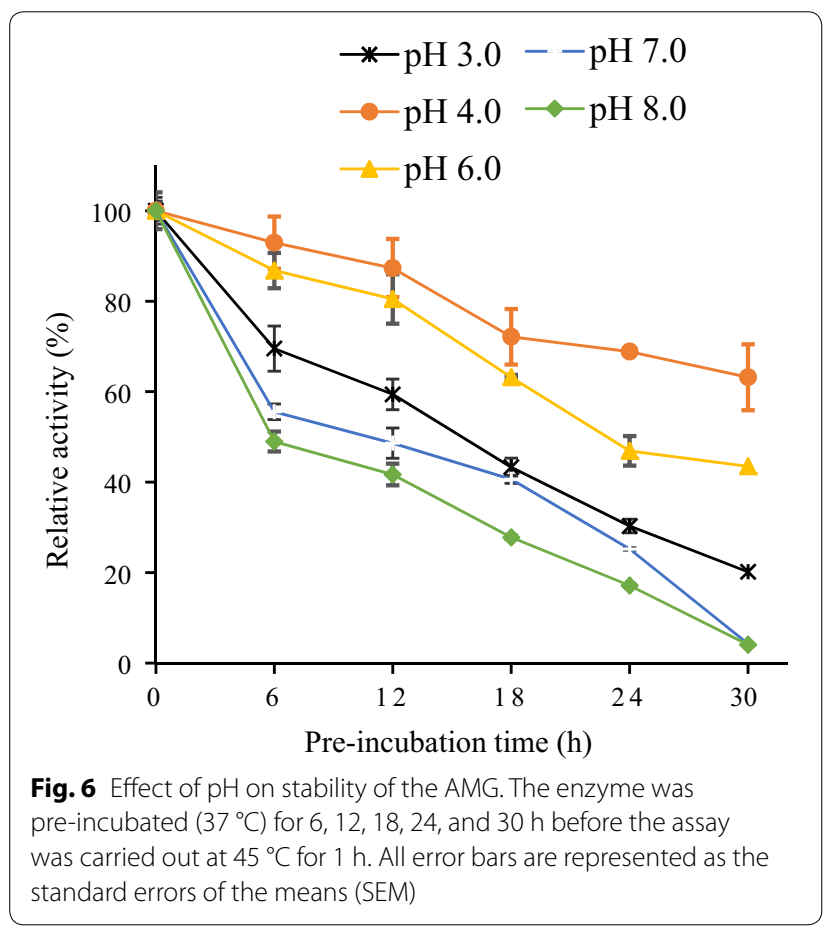

constant were calculated to be $70 \mathrm{~s}^{-1}$ and $184 \mathrm{mg} \mathrm{mL}^{-1}$ $\mathrm{s}^{-1}$, respectively.

\section{Discussion}

Amyloglucosidase enzyme was produced under liquidstate fermentation conditions using a modified MelinNorkrans medium. The elution profile on Sephadex G-100 was sufficient to obtain a single protein band which confirmed the purity of the enzyme. Thin layer chromatography patterns of the hydrolysis products demonstrated that only glucose was produced as an end product of enzyme activity (Fig. 2). This agrees with the reports that most fungi produced glucose as the product of AMG hydrolysis (Kusuda et al. 2004; Negi and Banerjee 2009; Slivinski et al. 2011). The product of the ammonium sulphate precipitation and the dialysis displayed specific activity values of 15.8 and $21.5 \mathrm{U} \mathrm{mg}^{-1}$ protein, respectively (Table 1 ). The amylase analysis by zymography revealed the formation of a single amylolytic band on the starch-SDS gel (indicative of a single isoform). After gel filtration, the enzyme was found to be homogeneous on SDS-PAGE (Fig. 4) with a specific activity value of $27.174 \mathrm{U} \mathrm{mg}^{-1}$ protein at a temperature of $37^{\circ} \mathrm{C}$. Furthermore, the findings on the SDS-PAGE showed many protein bands with no amylase activity except a single band of AMG which had a molecular weight of $101 \mathrm{kDa}$ (Fig. 4). This underpins the reports of some authors that the molecular weights of AMG in most fungi were within a range of 11.5-118 kDa (Hur et al. 2001; Nguyen et al. 2002; Kusuda et al. 2004; Slivinski et al. 2011).

The optimum $\mathrm{pH}$ and stability were determined (Figs. 5, 6), the optimum $\mathrm{pH}$ for AMG from was $\mathrm{pH}$ 4.0, and the enzyme was most stable at a $\mathrm{pH}$ of 5.0. A change in the $\mathrm{pH}$ of 1.0 unit resulted in decreased activity. The results were similar to the report of Slivinski et al. in 2011, who stated that the $\mathrm{pH}$ stability range for $A$. niger was within 4.0-6.0 at temperatures between 40 and $60{ }^{\circ} \mathrm{C}$. Kusuda et al. (2004) also reported that the glucoamylase obtained from an ectomycorrhizal fungus ( $L$. shimeji) was most active at around $40{ }^{\circ} \mathrm{C}(\mathrm{pH} 5.0)$ and stable at $\mathrm{pH}$ between 4.5 and 6.5 for $30 \mathrm{~min}$ at $37^{\circ} \mathrm{C}$. The AMG from L. incrustata was found to exhibit a steady activity at a temperature of $37{ }^{\circ} \mathrm{C}$ and $45{ }^{\circ} \mathrm{C}$, retaining over $65 \%$ of AMG activity up to $24 \mathrm{~h}$ at $45^{\circ} \mathrm{C}$ (Fig. 8). The activity declined with increased temperature. The stability of the AMG at $45^{\circ} \mathrm{C}$ was an improvement, considering the report of Hur et al. (2001) who revealed that the $\alpha$-amylase and glucoamylase from $T$. matsutake were only stable at $4{ }^{\circ} \mathrm{C}$ to $30{ }^{\circ} \mathrm{C}$ for $30 \mathrm{~min}$.

Some metal such as $\mathrm{Co}^{2+}, \mathrm{Hg}^{2+}, \mathrm{Cd}^{2+}$ and $\mathrm{Al}^{3+}$ have been reported to have an inhibitory effect on biomolecules (Tamás et al. 2014). The inhibitory effect of these metals $\left(\mathrm{Co}^{2+}, \mathrm{Hg}^{2+}\right.$ and $\left.\mathrm{Cd}^{2+}\right)$ on the AMG activity was significant to various degrees at all the concentrations tested (Table 2), but more pronounced at a concentration of $10 \mathrm{mM}$. It has been suggested that inhibition by $\mathrm{Hg}^{2+}$ and other heavy metal ions are not only related to binding to the thiol groups but may be the result of interactions with tryptophan residues or the carboxyl groups of amino acids in the enzyme (Selvakumar et al. 1996). For additives (other chemicals), the inhibitory effect of SDS on the AMG activity was the most significant (Table 3), this merely indicated that SDS is 


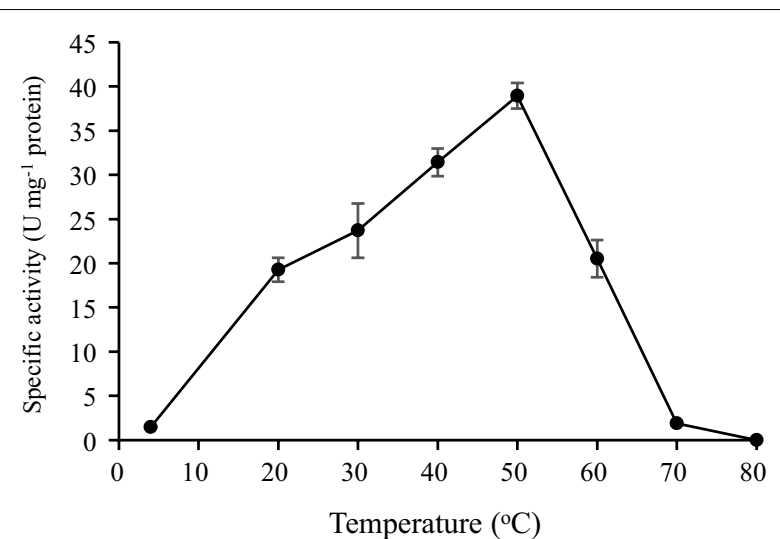

Fig. 7 Effect of temperature on the AMG activity. The enzyme was incubated at the temperature of 4 to $80^{\circ} \mathrm{C}$ for $1 \mathrm{~h}$. All error bars are represented as the standard errors of the means (SEM)

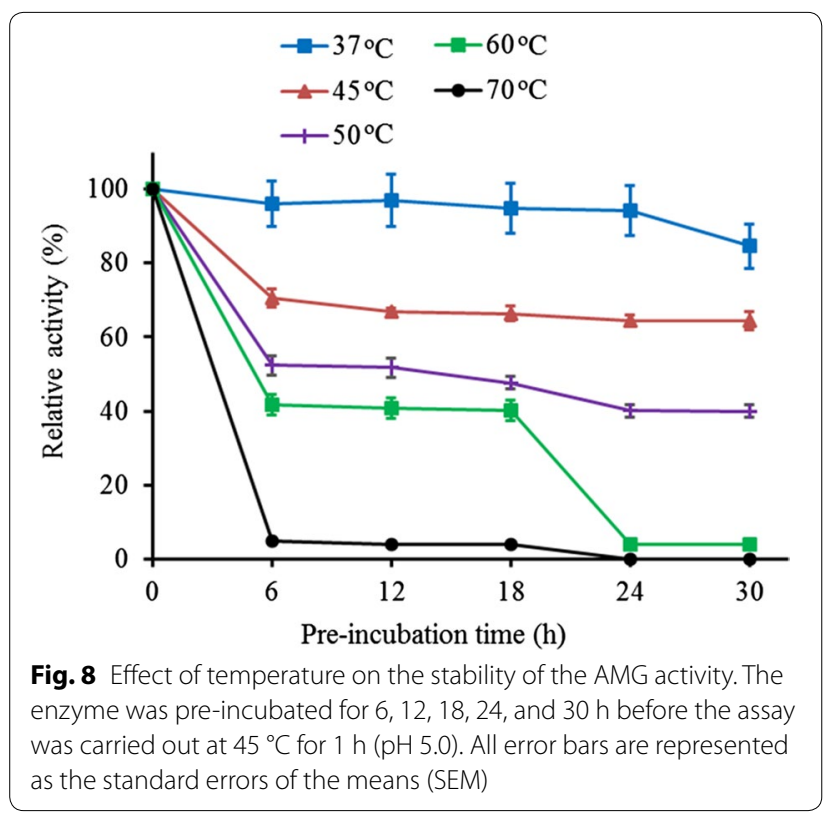

a denaturant (Michaux et al. 2008), while other tested additives were not inhibitory to the AMG activity. The AMG kinetics revealed that the activity increased with increased starch concentration, recording a $V_{\max }$ value of $22.56 \mathrm{U} \mathrm{mL}^{-1}$ and $K_{m}$ of $0.38 \mathrm{mg} \mathrm{mL}^{-1}$. This corroborates the report of Slivinski et al. (2011) who observed similar results. The AMG from L. incrustata had a high substrate affinity which suggested its suitability for industrial applications. Moreso, the AMG turnover number $\left(k_{c a t}\right)$ was $\left(70 \mathrm{~s}^{-1}\right)$ on soluble starch compared well with those of Humicola and Aspergillus species. Riaz et al. (2012) reported a $k_{\text {cat }}$ value of $69 \mathrm{~s}^{-1}$ for Humicola sp. and also, a much higher $k_{\text {cat }}$ value $\left(343 \mathrm{~s}^{-1}\right)$ was reported for $A$. niger (Riaz et al. 2012).
Table 2 Effect of the presence of metal ions on AMG activity

\begin{tabular}{lccc}
\hline Metal ion & $\begin{array}{l}\text { \% Relative activity } \\
(\mathbf{1 0 ~} \mathbf{~ m M})\end{array}$ & $\begin{array}{l}\text { \% Relative activity } \\
(\mathbf{5} \mathbf{~ m M})\end{array}$ & $\begin{array}{l}\text { \% Relative } \\
\text { activity } \\
(\mathbf{1 ~ m M})\end{array}$ \\
\hline $\mathrm{Mg}^{2+}$ & $98 \pm 4.7$ & $99 \pm 6.33$ & $100 \pm 3.87$ \\
$\mathrm{Na}^{+}$ & $102 \pm 9.78$ & $100 \pm 7.14$ & $101 \pm 6.14$ \\
$\mathrm{~K}^{+}$ & $96 \pm 5.66$ & $99 \pm 6.74$ & $101 \pm 6.97$ \\
$\mathrm{Al}^{3+}$ & $86 \pm 3.05$ & $95 \pm 5.68$ & $100 \pm 4.27$ \\
$\mathrm{Mn}^{2+}$ & $112 \pm 7.41$ & $102 \pm 2.8$ & $100 \pm 4.98$ \\
$\mathrm{Ca}^{2+}$ & $106 \pm 5.95$ & $100 \pm 2.17$ & $100 \pm 2.31$ \\
$\mathrm{Fe}^{2+}$ & $98 \pm 4.7$ & $100 \pm 1.18$ & $100 \pm 1.28$ \\
$\mathrm{Co}^{2+}$ & $77 \pm 3.51$ & $95 \pm 2.93$ & $100 \pm 3.95$ \\
$\mathrm{Hg}^{2+}$ & $0.45 \pm 0.05$ & $59 \pm 0.19$ & $92 \pm 2.23$ \\
$\mathrm{Cd}^{2+}$ & $4 \pm 0.23$ & $66 \pm 2.17$ & $100 \pm 3.16$ \\
\hline $\mathrm{Alva}^{2+}$ & & &
\end{tabular}

All values are represented by the standard errors of the means ( \pm SEM)

Table 3 Effect of the presence of additives on AMG activity

\begin{tabular}{lclc}
\hline Additive & $\begin{array}{l}\text { \% Relative activity } \\
(\mathbf{1 0} \mathbf{~ m})\end{array}$ & $\begin{array}{l}\text { \% Relative activity } \\
\mathbf{( 5 ~} \mathbf{~ M})\end{array}$ & $\begin{array}{l}\text { \% Relative } \\
\text { activity } \\
\mathbf{( 1 ~} \mathbf{~ m})\end{array}$ \\
\hline $\mathrm{NaN}_{3}$ & $100 \pm 7.28$ & $102 \pm 4.99$ & $101 \pm 5.28$ \\
$\mathrm{NH}_{4} \mathrm{Cl}$ & $101 \pm 1.69$ & $101 \pm 4.25$ & $101 \pm 8.05$ \\
EDTA & $92 \pm 5.59$ & $102 \pm 9.5$ & $102 \pm 6.73$ \\
$\mathrm{SDS}$ & $5.37 \pm 0.32$ & $39.8 \pm 1.64$ & $87.9 \pm 4.48$ \\
Tween20 & $99.7 \pm 1.75$ & $100 \pm 4.91$ & $101 \pm 5.77$ \\
DMSO & $99.7 \pm 8.12$ & $101 \pm 1.45$ & $102 \pm 3.12$ \\
IAA & $99.6 \pm 7.69$ & $102 \pm 8.88$ & $102 \pm 4.83$ \\
\hline
\end{tabular}

All values are presented by the standard errors of the means ( \pm SEM)

The $K_{m}$ and $k_{\text {cat }}$ values reported in this study were better than those reported by some authors. For example, $4.5 \mathrm{~g} \mathrm{~L}^{-1}$ and $45 \mathrm{~min}^{-1}$ were reported for Tetracladium sp. (Carrasco et al. 2017); $3.8 \mathrm{mg} / \mathrm{mL}$ and $41.7 \mathrm{~s}^{-1}$ for Paecilomyces variotii (Michelin et al. 2008) (Table 4).

In conclusion, the approach of sourcing enzymes from the environment is proving to be useful in producing novel enzymes that are suitable for the bioeconomy. Our L. incrustata is just one out of many ericoid mycorrhizal root endophytes that could be employed for the production of enzymes for the bioeconomy. This present study described, for the first time, the purification and characterization of an amyloglucosidase from L. incrustata. Keeping in mind, all the promising characteristics such as temperature stability over an extended period, high substrate affinity, stability to a range of chemicals and being non-pathogenic 


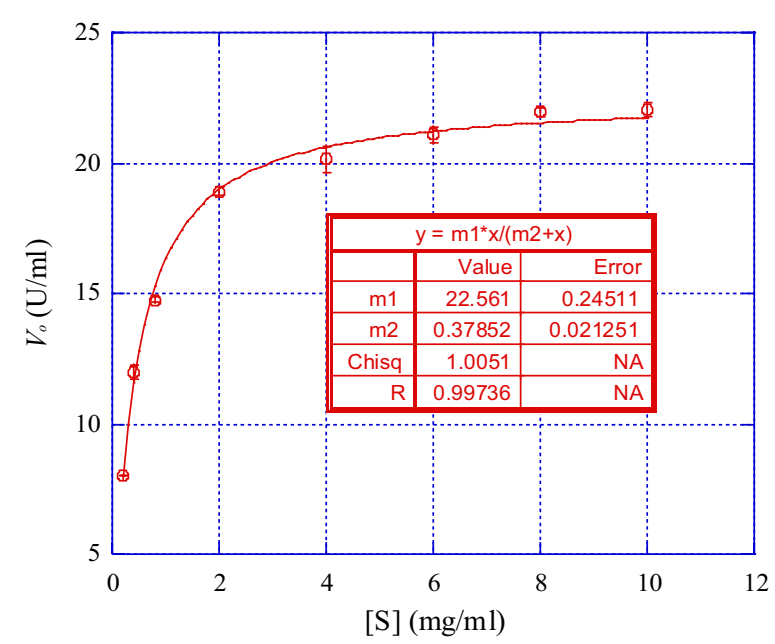

Fig. 9 Michaelis-Menten type kinetics of the purified AMG enzyme versus soluble starch concentration. All error bars are represented as the standard errors of the means (SEM) $\left(m^{1}=V_{\max }\right.$ and $\left.m^{2}=K_{m}\right)$

\section{Table 4 Comparison of the kinetic parameters of Leohumicola incrustata and other fungi}

\begin{tabular}{llll}
\hline Organism & $\boldsymbol{K}_{\boldsymbol{m}}\left(\mathbf{m g ~ m}^{\mathbf{- 1}}\right)$ & $\boldsymbol{k}_{\text {cat }}\left(\mathbf{s}^{\mathbf{- 1}}\right)$ & References \\
\hline Leohumicola incrustata & 0.38 & 70 & Current study \\
Humicola sp. & 0.26 & 69 & Riaz et al. (2012) \\
Aspergillus niger & 0.25 & 343 & Riaz et al. (2012) \\
Tetracladium sp. & 4.5 & 0.75 & Carrasco et al. (2017) \\
Paecilomyces variotii & 3.8 & 41.7 & Michelin et al. (2008) \\
\hline
\end{tabular}

make AMG a possible candidate for future application in industrial processes, for example, can be used in the production of bioethanol and glucose syrup.

\section{Abbreviations}

AMG: amyloglucosidase; ERM: ericoid mycorrhizal; SDS-PAGE: sodium sulphate dodecyl sulphate-polyacrylamide gel electrophoresis; TLC: thin layer chromatography; PDA: potato dextrose agar; DNS: dinitrosalicyclic acid; BSA: bovine serum albumin; TEMED: tetramethylethylenediamine; DMSO: dimethyl sulphoxide; EDTA: ethylenediaminetetraacetic acid; IAA: indole-3-acetic acid; SEM: standard errors of the means.

\section{Authors' contributions}

ORA, BIP and JFD designed the research; ORA preformed all the experiments and data analysis. All authors were involved in data interpretation and the writing of the paper. All authors read and approved the final manuscript.

\section{Author details}

${ }^{1}$ Department of Biochemistry and Microbiology, Rhodes University, P.O. Box 94, Grahamstown 6140, South Africa. ${ }^{2}$ Department of Microbiology, Adekunle Ajasin University, P.M.B. 001, Akungba-Akoko, Ondo State, Nigeria.

\section{Acknowledgements}

Isolates credit: Dr. Christine Bizabani, Rhodes University, Mycorrhizal Research Laboratory, Grahamstown, South Africa.

\section{Competing interests}

The authors declare that they have no competing interests.

\section{Availability of data and materials}

The fungal isolate used for this study was cultured from roots of ericaceous plants (Erica chamissonis) (Bizabani 2015). Leohumicola incrustata. (Isolate code ChemRU330/Genbank Accession Number MF374380/The South African National Collection of Fungi Accession Number PPRI 17268), was obtained from Mycorrhizal Research Laboratory, Rhodes University, Grahamstown.

\section{Consent for publication}

Not applicable

\section{Ethics approval and consent to participate}

This article does not contain any studies concerned with experiments on human or animals.

\section{Funding}

This study was funded by Rhodes University, Sandisa Imbewu Grant, South Africa and Adekunle Ajasin University/Tertiary Education Trust Fund (TETFund), Nigeria.

\section{Publisher's Note}

Springer Nature remains neutral with regard to jurisdictional claims in published maps and institutional affiliations.

Received: 12 July 2018 Accepted: 24 September 2018

Published online: 29 September 2018

\section{References}

Aiyer PV (2005) Amylases and their applications. Afr J Biotechnol 4:1525-1529 Bradford MM (1976) A rapid and sensitive method for the quantitation microgram quantities of protein utilizing the principle of protein-dye binding. Anal Biochem 72:248-254

Cairney JWG, Burke RM (1994) Fungal enzymes degrading plant cell walls: their possible significance in the ectomycorrhizal symbiosis. Mycol Res 98:1345-1356

Cairney JWG, Burke RM (1998) Extracellular enzyme activities of the ericoid mycorrhizal endophyte Hymenoscyphus ericae (Read) Korf and Kernan: their likely roles in decomposition of dead plant tissue in soil. Plant Soil 205:181-192

Carrasco M, Alcaíno J, Cifuentes V, Baeza M (2017) Purification and characterization of a novel cold-adapted fungal glucoamylase. Microb Cell Fact 16:75. https://doi.org/10.1186/s12934-017-0693-x

Hur T, Ka K, Joo S, Terashita T (2001) Characteristics of the amylase and its related enzymes produced by ectomycorrhizal fungus Tricholoma matsutake. Mycobiology 29:183-189

John J (2017) Amylases-bioprocess and potential applications: a review. Intl J Bioinform Biol Sci 5(2):41-50

Karim KMR, Husaini A, Tasnim T (2017) Production and characterization of crude glucoamylase from newly isolated Aspergillus flavus NSH9 in liquid culture. Am J Biochem Mol Biol 7(3):1 18-126

Kusuda M, Ueda M, Konishi Y, Matsuzawa K, Shirasaka N, Nakazawa M (2004) Characterisation of extracellular glucoamylase from the ectomycorrhizal mushroom Lyophyllum shimeji. Mycoscience 45:383-389

Laemmli UK (1970) Cleavage of structural proteins during the assembly of the head of bacteriophage T4. Nature 227:680-685

Martinez TF, Alarcon FJ, Moyano MDFJ (2000) Improved detection of amylase activity by sodium dodecyl sulfate-polyacrylamide gel electrophoresis with copolymerized starch. Electrophoresis 21:2940-2943

Michaux C, Pouyez J, Wouters J, Privé GG (2008) Protecting role of cosolvents in protein denaturation by SDS: a structural study. BMC Struct Biol 8:29

Michelin M, Ruller R, Ward RJ, Morais LAB, Jorge JA, Terenzi HF, Polizeli MLTM (2008) Purification and biochemical characterization of a thermostable extracellular glucoamylase produced by the thermotolerant fungus Paecilomyces variotii. J Ind Microbiol Biotechnol 35:17-25

Miller GL (1959) Use of dinitrosalicylic acid reagent for determination of reducing sugar. Anal Chem 31:426-428 
Morita H, Fujio Y (2000) Effect of organic nitrogen sources on raw starchdigesting glucoamylase production of Rhizopus sp. MKU 40. Starch/Stärke $52: 18-21$

Negi S, Banerjee R (2009) Optimization of extraction and purification of glucoamylase produced by Aspergillus awamori in solid-state fermentation. Biotechnol Bioprod Eng 14:60-66

Nguyen QD, Rezessy-Szabo JM, Claeyssens M, Stals I, Hoschke A (2002) Purification and characterisation of amylolytic enzymes from thermophilic fungus Thermomyces lanuginosus strain ATCC 34626. Enzyme Microb Technol 31:345-352

Rana N, Verma N, Vaidya D, Dipta B (2017) Application of bacterial amylase in clarification of juices and bun making. J Pharm Phytochem 6(5):859-864

Raveendran S, Parameswaran B, Ummalyma SB, Abraham A, Mathew AK, Madhavan A, Rebello S, Ashok Pandey A (2018) Applications of microbial enzymes in food industry. Food Tech Biotechnol 56(1):16-30

Riaz M, Rashid MH, Sawyer L, Akhtar S, Javed MR, Nadeem H (2012) Physiochemical properties and kinetics of glucoamylase produced from deoxyglucose resistant mutant of Aspergillus niger for soluble starch hydrolysis. Food Chem 130:24-30
Sauer J, Sigurskjold BW, Christensen U, Frandsen TP, Mirgorodskaya E, Harrison M (2000) Glucoamylase: structure/function relationships, and protein engineering. Biochimica et Biophys Acta 1543:275-293

Selvakumar PI, Ashakumary L, Helen A, Pandey A (1996) Purification and characterization of glucoamylase produced by Aspergillus niger in solid state fermentation. Lett Appl Microbiol 23:403-406

Singh R, Kumar M, Mittal A, Mehta PK (2016) Microbial enzymes: industrial progress in 21st century. 3. Biotechnology 6:174

Slivinski CT, Machado AVL, lulek J، Ayub RA, de Almeida MM (2011) Biochemical characterisation of a glucoamylase from Aspergillus niger produced by solid-state fermentation. Brazilian Arch Biol Technol 54:559-568

Smith SE, Read DJ (2008) Ericoid, orchid and mycoheterotrophic mycorrhizas. Mycorrhizal symbiosis, 3rd edn. Academic Press, New York, pp 387-507

Tamás MJ, Sharma SK, Ibstedt S, Jacobson T, Christen P (2014) Heavy metals and metalloids as a cause for protein misfolding and aggregation. Biomolecules 4:252-267

Zambare V (2010) Solid state fermentation of Aspergillus oryzae for glucoamylase production on agro-residues. Inter J Life Sci 4:16-25

\section{Submit your manuscript to a SpringerOpen ${ }^{\circ}$ journal and benefit from:}

- Convenient online submission

- Rigorous peer review

- Open access: articles freely available online

- High visibility within the field

- Retaining the copyright to your article

Submit your next manuscript at $\boldsymbol{\sim}$ springeropen.com 